СЛ.І.Білоусова, Н.В.Олефіренко, 2012 ISSN 2076-8184. Інформаційні технології і засоби навчання. 2012. №6 (32). Режим доступу до журналу: http://www.journal.iitta.gov.ua

УДК [373.31:37.026]:004

Білоусова Людмила Іванівна, кандидат фізико-математичних наук, професор, завідувач кафедри інформатики Харківського національного педагогічного університету імені Г. С. Сковороди, м. Харків, e-mail: lib215@list.ru

Олефіренко Надія Василівна, кандидат педагогічних наук, доцент, докторант кафедри теорії та методики професійної освіти Харківського національного педагогічного університету імені Г.С. Сковороди, м. Харків, e-mail: olefirenkonn@gmail.com

\title{
ДИДАКТИЧНІ ФУНКЦІЇ ЕЛЕКТРОННИХ НАВЧАЛЬНИХ РЕСУРСІВ для Молодших школяРів
}

\begin{abstract}
Анотація
Статтю присвячено висвітленню теоретичних засад функціонального підходу до застосування електронних ресурсів навчального призначення у початковій школі. Визначено й охарактеризовано сукупність основних дидактичних функцій електронних ресурсів; показано, що за провідною спрямованістю цих функцій їх можна систематизовано представити у вигляді чотирьох груп: функції формування позитивного ставлення учня до процесу і результату навчання, функції сприяння засвоєнню змісту навчання, функції оптимізації навчального процесу, функції, зорієнтовані на закладання основ успішності подальшого навчання школяра.

Ключові слова: електронні дидактичні ресурси, функції, початкова школа.

Постановка проблеми у загальному вигляді. Розвиток, удосконалення й розповсюдження інформаційно-комунікаційних технологій спричиняють істотний влив на всі компоненти навчального процесу — його цілі, зміст, завдання, форми, методи, засоби навчання. Найочевиднішими є зміни, що стосуються засобів навчання: використання електронних дидактичних ресурсів формує обличчя сучасної освіти [1].

Процеси інформатизації пронизують усі щаблі навчання, проте їх інтенсивність спадає від вищої до початкової школи. Певну уповільненість у застосуванні педагогічних програмних засобів для навчання молодших школярів зумовили численні застереження психологів, педагогів, медиків, фізіологів, гігієністів, які
\end{abstract}


звернули увагу на негативні аспекти залучення дитини до роботи 3 комп'ютером, наявність ризиків для іï здоров’я, можливість небажаних наслідків пї занурення у віртуальний світ. Попри це, нині ціла низка факторів дає поштовх до суттєвого розширення сфери використання електронних дидактичних ресурсів у початковій школі. Це перехід до неперервної шкільної інформатичної освіти, яка тепер розпочинається 3 2-го класу; наявність доступних високоякісних педагогічних програмних засобів для навчання предметів природничо-математичного i гуманітарного циклів; насиченість побуту сучасної людини цифровими пристроями, внаслідок чого до школи приходять діти зі сформованими користувацькими навичками, рівень яких виходить за межі елементарного; доведеність позитивного впливу роботи з комп'ютером на інтелектуальний розвиток учня, його мотивацію до навчання; зацікавленість батьків у модернізації шкільної, зокрема й початкової освіти з точки зору забезпечення кращої стартової позиції для їх дитини тощо.

3 вищезазначеного випливає, що використання електронних засобів навчання у початковій школі відрізняється певною специфікою: воно потребує педагогічного обгрунтування, чіткої спланованості, виваженості й обережності, точного підбору засобів як з точки зору сприяння досягненню поставленої дидактичній цілі, так і 3 точки зору врахування індивідуальних навчальних можливостей і потреб учнів. Окреслена специфіка актуалізує проведення досліджень, спрямованих на розробку наукових засад ефективного використання електронних дидактичних засобів у початковій школі.

Аналіз останніх досліджень і публікацій. Проблеми застосування електронних ресурсів у навчанні молодших школярів широко обговорюються у психолого-педагогічній літературі. Питанням викладання окремих дисциплін у початковій школі із застосуванням комп’ютера присвячені праці М. С. Цветкової, Д. В. Зарецького, З. О. Зарецької, Ю. А. Первіна, Н. В. Федянінової, В. В. Шакотька та інших. У дослідженнях П. М. Бісіркіна, Ю. О. Жука, Н. О. Толяренко розглядається вплив комп’ютерних засобів навчання на індивідуальні особливості молодших школярів. Проблеми створення дидактичних ситуацій з використанням комп'ютера у навчанні молодших школярів висвітлено в роботах В. М. Андрієвської. Питання розробки комплексу вимог до електронних дидактичних ресурсів знаходяться в полі зору багатьох психологів та педагогів, науковців i практиків, зокрема 
І. О. Анкудимової, М. І. Бєляєва, С. Г. Григор’єва, В. В. Гриншкуна, Г. А. Краснової, Г. П. Лаврентьєвої, А. В. Молокової, Н. В. Молоткової, О. В. Осіна, М. О. Свіряєвої, I. О. Смольнікової, М. П. Шишкіної та інших. Проблеми підготовки учителя до застосування інформаційних технологій у навчальному процесі висвітлені у грунтовних дослідженнях Г. В. Ломаковської, В. В. Коткової, Л. С. Пєтухової, О. В. Співаковського, О. В. Суховірського, О. І. Шиман. Разом $з$ тим, у педагогічній літературі не знайшли достатнього розкриття питання запровадження продуктивних підходів до реалізації дидактичного потенціалу електронних ресурсів у навчальному процесі початкової школи, що передбачає, перш за все, проведення теоретичних досліджень, спрямованих на з'ясування й розкриття сутності функцій таких ресурсів у навчанні молодших школярів.

Метою статті $\epsilon$ висвітлення й систематизація дидактичних функцій електронних ресурсів для початкової школи.

Виклад основного матеріалу дослідження. Потужний дидактичний потенціал електронних навчальних ресурсів $є$ незаперечним, проте визначальним чинником його ефективної реалізації у практиці навчання $\epsilon$ свідома опора на ті чи інші дидактичні функції, які є суттєвими в ракурсі розв'язання певного педагогічного завдання. Саме це складає основу проектування дидактичних ситуацій, у розв'язанні яких використання електронних ресурсів становить центральний момент.

Розкриття спектру дидактичних функцій електронних ресурсів у навчанні молодших школярів представляє інтерес і з іншої точки зору. Існуючі обмеження медичного, санітарно-гігієнічного характеру зумовлюють певні вимоги до застосування таких ресурсів у початковій школі, які стосуються терміну роботи учня 3 комп’ютером, ергономічних якостей інтерфейсу програмного засобу, використання колірної гами, специфічних виразних засобів тощо. У поєднанні 3 вимогами дидактичного характеру, які стосуються точності орієнтації ресурсу на досягнення поставленої цілі, відсутності сторонньої інформації, доступності для учнів даного класу тощо, зазначені обмеження ускладнюють вибір потрібного ресурсу серед наявних. У таких випадках найприйнятнішим виходом $є$ створення вчителем авторського електронного ресурсу, що потребує обізнаності не тільки 3 практикоорієнтованими технологіями й інструментальними засобами проектування [2], а і 3 його теоретичним підгрунтям - дидактичними функціями електронних ресурсів. 
Проведений аналіз психолого-педагогічної літератури 3 проблем розробки електронних дидактичних ресурсів, а також практики їх застосування дав змогу виявити спектр основних функцій цих ресурсів у навчанні молодших школярів. Попри різноплановість і розмаїття виокремлених функцій, вони є взаємопов’язаними i взаємоузгодженими: якість реалізації одних зумовлює і впливає на якість реалізації інших.

Висвітлення сутності досліджуваних функцій потребує їх попередньої систематизації, в основу якої нами покладено спорідненість провідного спрямування. Такий підхід дав підставу для виділення чотирьох груп функцій:

перша група містить функції, що сприяють формуванню позитивного ставлення дитини до процесу і результату навчання. До цієї групи віднесено функції:

- розвитку власних мотивів школяра до виконання навчальних дій;

- відслідковування і схвалення успішних дій учня;

- створення сприятливого емоційного фону;

- реалізації зв’язку змісту навчання з життям;

у другій групі зібрані функції, що забезпечують успішність школяра у засвоєнні змісту навчання. До цієї групи віднесено функції:

- візуалізації;

- тренінгові;

- корекції набутих знань й умінь;

- інтеграційну;

- адаптаційну;

- забезпечення своєчасної допомоги в опануванні змісту навчання;

- компенсаторну;

третю групу складають функції оптимізації навчального процесу, а саме функції:

- контрольна;

- діагностична;

- моніторингова;

- інтенсифікації навчального процесу;

у четверту групу об’єднані функції, зорієнтовані на закладання основ успішності подальшого навчання школяра. Ця група включає функції, які $\epsilon$ 
важливими для поточного навчального процесу, але мають перспективний характер і сприяють становленню пізнавальної діяльності школяра. До цієї групи віднесено функції:

- інструментальну;

- дослідницьку;

- розвитку інтелектуальних умінь;

- мобілізаційну;

- сприяння формуванню цілісного світогляду.

Наведемо стислу характеристику перелічених функцій, розглядаючи їх за виокремленими групами.

Функції формування позитивного ставлення дитини до процесу результату навчання. Формування потреб і мотивів діяльності школяра відбувається у процесі здійснення самої діяльності [3, 4], тому для виникнення, зміцніння й розвинення пізнавальних мотивів учня слід залучити його до навчальної діяльності і створити умови, за яких така діяльність викличе у нього інтерес і яскраві позитивні емоції. Саме це й надають змогу зробити електронні дидактичні ресурси.

В електронних дидактичних ресурсах функція розвитку мотивів школяра до виконання навчальних дій реалізується за рахунок: ненав'язливого втягнення учня до навчально-пізнавальної діяльності, до якої він залучається не за прямими вказівками вчителя, а за власним бажанням розв'язати ситуацію, що виникає на екрані комп’ютера; варіативності навчальних завдань, урізноманітнення способів їх подання й оформлення, що надає привабливості звичайному процесу відпрацювання навичок; можливості їх «авторизації» школярем - можливості модифікації засобу за рахунок включення матеріалів, що відбивають особистісний досвід школяра.

Дитина молодшого шкільного віку потребує постійної уваги до результатів їі діяльності, схвалення iï успіхів, підбадьорення при невдачах. Функція відслідковування $i$ схвалення успішних дій учня реалізується в електронних дидактичних ресурсах за рахунок їх здатності відслідковувати динаміку досягнень школяра й відразу відмічати найменші позитивні зрушення. Наразі відміченим може бути не тільки покращення результату в цілому, але й найменші досягнення за окремими показниками, такими як збільшення кількості правильно розв’язаних 
завдань за одиницю часу, зменшення кількості спроб, отриманих підказок, допущених помилок тощо.

Не менш важливою для формування позитивного ставлення дитини до навчання є створення сприятливого емоційного фону для навчальної діяльності. Застосування електронних дидактичних ресурсів на уроці, як правило, не залишає жодного школяра байдужим. Формуванню позитивних емоцій та естетичних почуттів сприяє приємний інтерфейс ресурсу, гармонійно підібрана колірна гама, використання спеціальних прийомів для привертання і зосередження уваги школяра, розвитку його уяви, мислення, пам'яті. Створенню позитивного емоційного фону сприяє також можливість у будь-який момент скасувати виконані дії і повернутися до попереднього кроку. Для пошуку правильного або ефективного способу розв’язання навчального завдання учень може здійснювати кілька спроб без побоювань будь-яких негативних наслідків.

Для реалізації зв'язків змісту навчання з життєвими реаліями використання електронних дидактичних ресурсів розширює можливості. Навчальне завдання на екрані комп'ютера може бути поданим 3 усіма потрібними йому атрибутами: наприклад, предметами, які потрібно зважити, кошиком, у якому вони містяться, терезами та гирями для зважування.

Цілком реальними можуть бути змодельовані у завданнях ситуації придбання товарів у магазині, подорож у місцевому транспорті, відправденння смсповідомлення тощо, де використовуються справжні ціни товарів, вартість проїзду, ціна мобільного зв’ язку — такі, з якими дитина стикається у повсякденному житті.

Наближеною до реальності може бути сама постановка завдання не тільки за формулюванням, а й за варіативністю можливих розв’язків. Електронні ресурси дають змогу запропонувати задачу на раціональний вибір способу іï розв'язання. Наприклад, знайти спосіб дістатися в заданий пункт у найкоротший термін, придбати найбільшу кількість товарів певного виду на визначену суму грошей тощо.

У середовищі електронного дидактичного засобу стає доступною для учня й така діяльність, яка пов'язана 3 розв'язанням завдання, але не може бути реалізованою в умовах класу. Наприклад, учень може «переливати» рідину з одного посуду в інший, «розсаджувати» рослини, «розрізати» пиріг, «переходити» дорогу, по якій рухається транспорт, тощо. 
Функції сприяння засвоснню змісту навчання. У багатьох психологопедагогічних дослідженнях функція візуалізації визначається як провідна функція електронних дидактичних засобів. Важливість цієї функції зумовлена такими факторами, як ємність візуального способу подання інформації, можливість підвищити за цей рахунок доступність навчального матеріалу для учнів, збільшити обсяг навчального матеріалу, який піддається засвоєнню в межах окремого уроку. У сучасних умовах зростанню значимості розглядуваної функції сприяють такі фактори, як поява новітніх потужних технологій візуалізації об'єктів найрізноманітнішої природи, зростання якості виразних засобів комп'ютерної графіки, налаштованість молодого покоління на сприйняття візуальної інформації.

В електронних дидактичних засобах візуалізація об'єкта навчання є керованою: будь-який фрагмент можна переглянути повторно, швидкість показу процесу можна регулювати, що дозволяє демонструвати процеси, перебіг яких відбувається занадто швидко або повільно. Візуалізації піддаються явища і події, відтворення яких в реальних умовах не є можливим. Так, можна ознайомити учнів 3 подіями минулих часів, з неповторними або небезпечними явищами тощо.

Використання електронних ресурсів істотно розширює спектр i якість доступних для застосування у навчанні ілюстративних матеріалів: традиційно використовувані рисунки, фотографії, репродукції доповнюються анімованими зображеннями, флеш-ілюстраціями, відеозйомками реальних подій, оцифрованими раритетними матеріалами - історичними архівними документами, унікальними книжковими виданнями, фотографіями минулої епохи тощо. Серед візуальних засобів на особливу увагу заслуговують схеми і таблиці, які широко використовуються в практиці навчання і можуть бути достатньо місткими i включати як компактне подання поточного навчального матеріалу, так і демонстрацію його логічних зв’ язків 3 поняттями, що були вивчені раніше в рамках цієї або іншої дисципліни.

Цінність реалізації функції візуалізації в електронних дидактичних ресурсах полягає в тому, що дає змогу із самого початку ознайомлення школяра 3 новими об'єктами сприяти створенню про них правильних уявлень, які в процесі подальшого навчання підлягають поглибленню й уточненню, але не потребують виправлення й коригування. 
Розглядаючи тренінгову функцію, зазначимо, що в початковій школі велика увага приділяється формуванню й удосконаленню предметних і загальнонавчальних навичок, які необхідні для подальшого збільшення темпу навчання за рахунок оперування укрупненими дидактичними одиницями. У практиці роботи вчителя саме цей тренувальний напрям викликає утруднення, зумовлені різними потребами кожного школяра в кількості і наборі тих вправ, які йому потрібні для відпрацювання певних умінь й переведення їх засвоєння на рівень навичок. Індивідуалізація такого набору вправ для учня в умовах шкільного навчання наштовхується на цілком зрозумілі труднощі.

Суттєвою в даному аспекті особливістю електронних тренажерів є можливість регулювання основних параметрів комплекту завдань, пропонованих школяреві — їх кількості, трудності, складності. Такі параметри можуть бути попередньо заданими визначеними вчителем або обраними учнем, але особливий інтерес представляють тренажери, які реалізують адаптивні алгоритми роботи і на основі виконання учнем перших «пробних» завдань автоматично коригують рівень трудності й складності, а також кількість наступних. Такі адаптивні тренажери корисні для використання саме в початковій школі, адже різниця у підготовці школярів, наявному рівні їх умінь i навичок $є$ найбільш відчутною. Автоматичне управління рівнем трудності завдань дає змогу підтримувати школяра в зоні його найближчого розвитку.

Перевагою електронних тренажерів є можливість забезпечити варіативність завдань, неповторюваність вправ, призначених для формування відповідних навичок, надати ігрового і змагального забарвлення виконуваним вправам. Ігрова форма подання завдань, іiі динамічний характер, практична мета (розфарбувати малюнок, зібрати ключі, визволити принцесу тощо) перетворює рутинну роботу 3 відпрацювання навичок на цікаву гру, що мотивує школяра до виконання типових завдань.

Значимість функиії корекщіï набутих знань й умінь молодших школярів зумовлена тим, що найменші прогалини у їх навчанні впливають на якість усвідомлення і засвоєння подальшого матеріалу [5]. Вчасне виявлення і виправлення прогалин у знаннях, усунення помилкових уявлень та неточностей у розумінні тих чи інших понять школярами потребує професійної майстерності вчителя. У той же час 
електронний ресурс може надати суттєву допомогу в такій роботі кожному вчителеві. Корекційна функція електронних дидактичних ресурсів реалізується за рахунок:

- миттєвої реакції комп’ютера на дії школяра;

- застосування різних способів виявлення утруднень школяра - як явних (шляхом контрольних запитань або завдань), так і неявних (шляхом вимірювання часу, потрібного школяреві для відповіді, або проміжку часу, протягом якого користувач залишається бездіяльним, шляхом урахування кількості звернень користувача за підказками й фіксації тих ситуацій, у яких підказки знадобилися школяру);

- реалізації різних варіантів коригування дій школяра - прямих, коли виправляється неправильна дія школяра, демонструється та пояснюється хід розв’язання завдання, та непрямих, коли надається інформація, яка допомагає учневі зробити правильний вибір.

Інтеграційна функиія полягає в інтеграції всіх етапів навчання в одному програмному засобі і відбувається за рахунок того, що матеріал подається невеликими логічно завершеними порціями 3 використанням різних способів утримання уваги учня або її зосередження на важливих моментах. Подання матеріалу поєднується з перевіркою його розуміння, супроводжується демонстрацією зразків розв’язання завдань i/або залученням школяра до виконання вправ тренувального характеру. Інтерактивність електронного засобу дає змогу здійснювати неперервний контроль за діями учня і не допускати формального перегляду навчального матеріалу або того, щоб якась його частина залишилася незрозумілою дитині.

Адаптаційна функиія електронних дидактичних ресурсів характеризує можливість їх використання для створення персоналізованого навчального середовища учня, у якому відбувається його навчальна діяльність, накопичуються $\mathrm{i}$ зберігаються об’єктивні показники, що характеризують іiі перебіг, результати i специфічні особливості, а також реалізуються комфортні умови для такої діяльності, що враховують особистісні потреби й уподобання учня. Персоналізація навчального середовища реалізується також за рахунок варіативності подання інформації відповідно до індивідуальних особливостей сприйняття i мислення школяра; варіативності видів діяльності, які може реалізувати школяр у цьому середовищі, зокрема, здійснюючи вибір власної діяльності, рівня трудності завдань, рівня 
засвоєння навчального матеріалу, теми для опанування; варіативності інструментів навчальної діяльності, якими може скористатися учень. Завдяки таким можливостями навчальна діяльність змінюється - учень стає вільним у виборі власного шляху навчання, стає центром навчального процесу і будує його відповідно до власних потреб.

Вчасна допомога $є$ неодмінною умовою успішності молодшого школяра у навчанні. В електронних дидактичних засобах функція забезпечення своєчасної допомоги в опануванні змістом навчання реалізується за рахунок супроводу діяльності школяра індивідуалізованими підказками, вказівками, поясненнями тощо. Така допомога учневі може надаватися як за його запитом, так й автоматично. Сигналом про необхідність допомоги може слугувати тривала затримка школяра 3 початком роботи або з виконанням очікуваних дій, значна кількість неправильних спроб у розв’язанні нескладних завдань тощо. Рівень допомоги може варіюватися від стислих вказівок до демонстрації деталізованого розв'язку завдання з поясненнями.

Наразі, забезпечення успішності навчальної діяльності кожного школяра має відбуватися за збереження гранично доступного для подолання ним рівня трудності пропонованих завдань.

Компенсаторна функція полягає у подоланні невідповідності умов шкільного навчання індивідуальним особливостям і потребам учня. Це призводить до того, що дитина виявляється змушеною пристосовуватися до умов навчання, а не навпаки. Компенсаторна функція електронних дидактичних ресурсів спрямована на створення оптимальних умов для реалізації потенційних можливостей кожного учня i забезпечення його прогресування, для розкриття таланту, притаманного кожній дитині, схованого скарбу її обдарувань й сприяння їх розвитку. Реалізація цієї функції спирається на ті властивості електронних ресурсів, які були розглянуті в ході висвітлення попередніх функцій - тренінгової, адаптаційної, інтеграційної, корекційної, функції надання своєчасної допомоги. Разом 3 тим, вважаємо за необхідне виокремити компенсаторну функцію, зважаючи на ії значимість 3 точки зору розстановки правильних акцентів у навчанні, цінність якого полягає в отриманні високих результатів не за показниками в оціночному вимірі, а за так званою «додатковою вартістю», тобто за прогресом, досягнутим кожним окремим учнем. 
Функції оптимізації навчального процесу. Оптимізація навчального процесу з необхідністю передбачає збирання інформації про його перебіг та результативність, тобто спирається на проведення заходів щодо контролю, діагностики та моніторингу навчального процесу. У педагогічній науці ці поняття часто змішують. Причинами такого змішування $\epsilon$ те, що як контрольні, так і діагностичні та моніторингові процедури включають збирання даних про рівень навчальних досягнень учнів, використовують спільні методи одержання інформації.

На нашу думку, найбільш глибока різниця між функціями контролю й діагностики навчального процесу полягає в їх провідній спрямованості: контрольна функція, перш за все, адресована тому, хто навчається, допомагаючи йому з'ясувати ступінь успішності власної навчальної діяльності, виявити і ліквідувати допущені прогалини; діагностична функція адресована педагогу, який має визначити не тільки відповідність результатів навчання заданому еталону (стандарту, вимогам, поставленій меті), а й причини відхилень між запланованими і досягнутими результатами. На відміну від контролю й діагностики, моніторинг передбачає тривале спостереження за результатами навчальної діяльності школяра, класу з метою отримання об’єктивної інформації прогностичного характеру, необхідної для управління якістю навчального процесу.

Оцінюючи значення контрольної функції, зазначимо, що в початковій школі від правильної організації контролю навчальної діяльності значною мірою залежить успішність дитини. Основним видом контролю у початковій школі є поточний, який спрямований на отримання оперативної інформації про навчальні досягнення учнів. У середовищі електронних дидактичних ресурсів контроль набуває неперервного характеру і реалізується в інтеграції з навчанням у явному і неявному вигляді: усі дії школяра відстежуються, накопичуються дані про його утруднення, кожна нова порція навчального матеріалу надається за умови певного підтвердження засвоєності попередньої. Важливим є те, що контроль у педагогічних програмних засобах не створює для школяра психологічної напруги i сприймається ним як природний супровід навчання, як діалог із навчальним середовищем.

Для тематичного i підсумкового контролю використовуються засоби комп'ютерного тестування, визнаними особливостями яких $є$ об'єктивність контролю, його оперативність, багатопараметричність (поряд 3 даними про 
правильність виконання тесту система може явно або неявно збирати значну кількість додаткових даних про процес роботи учня), інформативність (можливість визначати за результатами тестування не тільки рівень, а й структуру навчальних досягнень учня, його індивідуальні особливості, психологічну готовність до тестування тощо).

Крім того, відзначимо такі особливості комп'ютерного тестування: можливість виключити вплив випадкових факторів на результати контролю; можливість скорочення процедури контролю за рахунок застосування адаптивних алгоритмів; можливість регулювання режиму роботи програми залежно від потреб уроку.

Для молодших школярів важливими є також такі специфічні особливості програм електронного тестування:

- сюжетне оформлення процедури контролю, яке надає йому привабливого характеру, дозволяє уникнути зайвого напруження й виконує стимулюючу функцію;

- посилення мотивації до виконання завдань за рахунок поєднання контрольної діяльності з ігровою;

- надання змагального характеру виконанню завдань;

- змінення видів діяльності у процесі контрольних заходів;

- негайність отримання результатів перевірки, що сприяє вчасному виправленню помилкових уявлень;

- розмаїття форм пред’явлення результатів перевірки - замість звичної репліки (правильно-неправильно) використовуються анімаційні засоби, музичне оформлення.

Діагностична функція електронних дидактичних засобів полягає у допомозі вчителеві оцінити дії учня у програмному середовищі, у якому здійснюється навчання, тренування або перевірка успішності школяра, з'ясувати причини неправильних дій дитини, визначити, у чому саме полягають ії утруднення. Така функція реалізується шляхом непомітного для учня збирання і накопичення значної кількості інформації, яка дає змогу діагностувати його стан, ступінь уважності, специфіку реакції на запити програми, час, потрібний для обдумування відповіді, тощо. Ця інформація допомагає вчителю виявити індивідуальні особливості школяра, які впливають на його успішність, скласти об’єктивне уявлення про особистість дитини, визначити, у якому вигляді інформація школярем сприймається найкраще. 
Зазначимо, що можливість збирання даних про процес навчання школяра, здійснення їх статистичної обробки й побудови прогнозів лежить в основі адаптивних програм-тренажерів і навчаючих програм, які здатні підтримувати інтелектуальний діалог $з$ учнем.

Моніторингова функція електронних дидактичних ресурсів полягає у накопиченні, систематизації та здійсненні статистичного аналізу значних обсягів даних про кожного школяра: показників його навчальної діяльності, даних про відвідування дошкільних та позашкільних закладів (спортивних, розвивальних тощо), відомостей про сім’ю (iі матеріальний стан, освітній рівень батьків тощо). Такий аналіз дає змогу вчителю визначити фактори, які дійсно впливають на якість навчальної діяльності конкретного школяра, виявити іiі тенденції, спрогнозувати майбутні результати.

Оптимізація навчання передбачає також інтенсифікацію навчального процесу, яку можна розглядати з двох позицій: з точки зору продуктивності часових витрат і 3 точки зору щільності навчального процесу [6]. Реалізація функиії інтенсифікації навчального прощесу в електронних дидактичних засобах здійснюється завдяки:

- візуалізації інформації, яка сприяє кращому розумінню змісту навчального матеріалу, сутності пропонованих завдань і дозволяє уникнути додаткових пояснень, забезпечити компактність викладу інформації;

- автоматизації виконання рутинних дій, що дає змогу сконцентрувати зусилля учнів на ключових операціях;

- забезпеченню найкоротшого шляху школяра до потрібної інформації. На відміну від звичайних підручників, програмні засоби не обмежені рамками навчальної книги і містять не тільки основні, а й багато допоміжних та розширених відомостей $з$ навчального предмета, цікавих матеріалів для допитливих тощо. Доступ школяра до потрібного фрагменту здійснюється майже миттєво - за ключовими словами, гіперпосиланнями;

- можливості створення школярем власної траєкторії навчання, отримання тієї інформації, яка релевантна його індивідуальним запитам, потребам і схильностям. Відповідність змісту навчання індивідуальним потребам спонукає школяра до активності, у результаті чого обсяг інформації, яку він сприймає і засвоює, зростає. 


\section{Функції закладання основ успішності у подальшому навчанні.}

Характеризуючи інструментальну функцію, слід взяти до уваги, що початкова школа є тим етапом, коли комп'ютер для дитини перестає бути виключно засобом розваги, а перетворюється на інструмент іiі предметної i творчої діяльності. У такому перетворенні провідну роль відіграє систематичне використання електронних дидактичних засобів у шкільному навчанні, у процесі якого школяр оволодіває:

- стандартними інструментам управління програмним засобом, такими як стандартні пристрої (клавіатура, миша); інтерфейсні елементи (кнопки, меню, списки, поля уведення), способи отримання допомоги (пункт меню, кнопка підказки тощо);

- новим інструментарієм предметної діяльності, такими як комп'ютерні інструменти художньої творчості (фарби, ножиці, пензлі, масштабування, копіювання, інструменти роботи 3 кольором, інструменти створення спецефектів тощо); пристрої віртуальної реальності (джойстрінг, інтерфейсрукавички, окуляри-телемонітори, інформаційний костюм); інструменти дослідження (мікроскоп, телескоп, геосервісні інструменти); комп’ютерні інструменти вимірювання (годинник, лінійка, транспортир, термометр, інструменти вимірювання освітленості, рівня шуму, кількості серцевих скорочень);

- основними інструментами масових цифррових технологій, такими як комп’ютерні інструменти роботи з текстами і рисунками; інструменти обробки аудіо-, фото, відеозаписів; інструменти подання і відображення інформації у вигляді діаграм, гістограм, ментальних карт тощо; інструменти створення власних електронних матеріалів (презентацій, оформлених вітальних листівок, творів).

Слід окремо зупинитися на застосуванні засобів масових інформаційних технологій (наприклад, пакета Microsoft Office) у початковій школі. Аргументами на користь такого застосування $€$ перспективність набуття учнем навичок роботи 3 реальними програмними продуктами, а не їх емуляторами, а також простота використання найбільш уживаних інструментів, які зібрані окремо, є легко доступними i достатніми для виконання простих завдань. Складнішими інструментами дитина має змогу оволодівати поступово, до того ж надлишковість 
функціональних можливостей реальних програмних продуктів спонукає школяра до подальшого самостійного опанування нових інструментів і способів оперування ними.

Дослідницьку функцію електронних дидактичних ресурсів ми розуміємо як підтримку дослідницької діяльності школяра в комп’ютерному середовищі. Ця підтримка виявляє себе в таких аспектах:

- об’єктному, оскільки розширюється коло об’єктів, які учень може досліджувати або з якими він може виконувати різні маніпуляції, залишаючись у безпеці і зберігаючи можливість відмінити свої дії і повернуться на один чи більше кроків назад;

- інструментальному - школяреві надаються зручні інструменти для оперування об' єктом на екрані комп'ютера;

- інформаційному, оскільки дитина отримує інформацію про кількісні зміни, які відбуваються з об’ єктом у результаті виконаних дій.

Зазначимо, що можливість і необхідність дослідницької діяльності молодших школярів обгрунтована в численних педагогічних $\mathrm{i}$ психологічних працях Т. М. Байбари, В. В. Давидова, Г. С. Костюка, І. Я. Лернера, О. Я. Савченко, Д. Б. Ельконіна тощо. Включення учня у дослідницьку діяльність цілком відповідає його віковим потребам, адже в цьому віці ще зберігається природна допитливість й цікавість дитини, вона багато експериментує й відкриває для себе правила й закони. Використання електронних дидактичних ресурсів дає змогу зберегти й розвинути допитливість школяра, його бажання самостійно про щось дізнатися, у чомусь переконатися. Більше того, можливість маніпулювати з різноманітними об'єктами на екрані комп'ютера сприяє розвитку у молодшого школяра здатності осмислювати свою пізнавальну діяльність. Впливаючи на об'єкт і обмірковуючи його реакцію, він навчається осмислювати свої дії, планувати кроки до здійснення наміру, ставити задачу й знаходити шляхи ії розв’язання [7].

Електронні ресурси навчального призначення, зорієнтовані на підтримку дослідницької діяльності молодших школярів, можуть провокувати школяра на самостійне відкриття загальних правил із часткових, на формулювання висновків із ситуацій. 
Реалізації функиії розвитку інтелектуальних умінь школярів у процесі використання електронних дидактичними ресурсів сприяє:

- складність комп'ютерних інструментів, якими учень оволодіває у процесі роботи з програмним засобом. Ця складність зумовлена необхідністю розуміння умовних позначень операцій на екрані комп'ютера; потребою у співвіднесенні власних рухів щодо переміщення миші або джойстика зі змінами, які відбуваються на екрані комп’ютера; варіативністю способів виконання дій з об' єктами; необхідністю засвоєння специфічних комп'ютерних навичок щодо маніпуляції з об' єктами;

- занурення школяра в інформаційно насичене середовище, яке передбачає варіативність дій, надлишковість інформації і наштовхує школяра на формулювання питань і пошук відповідей на них [8];

- варіативність сюжетного оформлення навчальних завдань, нестандартність й різноманітність ситуацій, у які занурюється учень у процесі роботи з електронними ресурсами, що формує у школяра уміння сприймати інформацію, представлену у різних формах; аналізувати іiі, планувати на цій основі свої подальші дії;

- залучення школяра до здійснення самостійного свідомого вибору правильної відповіді, рівня складності завдання, виду допомоги тощо.

Мобілізаційна функція електронних дидактичних ресурсів полягає у створенні умов, які спонукають школяра до активізації набутих знань і їх застосування для розв’язання проблемної ситуації, вибору способу дій або розв’язання поставленого завдання. Ця функція реалізується за рахунок:

- $\quad$ розмаїття і непередбачуваності ситуацій, у яких учень має виявити наявні знання, уміння та навички;

- створення ситуацій, які потребують від учня швидкої реакції, нестандартної поведінки, комбінування раніше вивчених способів дій;

- надання змагального характеру роботі учня у середовищі програмного засобу, що стимулює школяра до мобілізації знань для отримання кращих результатів — порівняно з іншими користувачами або з власними попередніми досягненнями;

- моментальної реакції програмного засобу на дії користувача, що підштовхує школяра до адекватної оперативності у подальших діях - у виборі способу дій, у прийнятті рішення тощо. 
Функиія формування иілісного світогляду посідає окреме місце в групі функцій, що розглядаються. Світогляд $є$ системою принципів, поглядів, цінностей, ідеалів, які визначають ставлення дитини до дійсності, загальне розуміння світу, життєві позиції [9]. У структурі світогляду виділяють такі елементи [9], [10]:

- світорозуміння - система уявлень про світ крізь призму духовного досвіду суспільства, особистості (пізнавально-інтелектуальний рівень);

- світовідчуття - чуттєво-емоційне переживання людиною свого буття у світі (емоційно-психологічний рівень);

- світовідношення - особистість ставиться в активну позицію пізнання, тлумачення, життєдіяльності (наявність у світогляді спонук до активності).

Формуванню цілісного світогляду учня у процесі використання електронних дидактичних ресурсів сприяє те, що сучасні цифрові технології здатні створити на екрані комп'ютера реалістичне подання тих об’єктів, що вивчаються, забезпечуючи їх візуальне, аудіальне і навіть тактильне сприйняття дитиною, тим самим надаючи ій змогу отримати реальні відчуття зіткнення з навколишнім світом.

Становленню гуманістичних позицій учня сприяє те, що в програмних засобах для дітей молодшого шкільного віку використовуються так звані «педагогічні агенти», які оточують дитину у віртуальному світі і завжди готові прийти ій на допомогу. Вони наділені терпимістю, привітністю, чуйністю, і школяр сприймає норми тактовних, коректних, доброзичливих взаємин.

Робота 3 програмними засобами формує світовідчуття й світовідношення школяра за допомогою сюжетного характеру тих навчальних завдань, які ставляться перед ним. Ці завдання пов'язані з благородними, гуманними, творчими цілями допомогти позитивному герою врятувати принцесу, знайти ключ, досягти іншої планети, побудувати будинок тощо. У середовищі педагогічного програмного засобу школяр не стикається 3 агресією у будь-яких іï проявах, тут панує верховенство добра, утвердження загальнолюдських цінностей.

Використання електронних дидактичних ресурсів допомагає налаштовувати школяра на активність у пізнанні світу. Він не $є$ пасивним читачем навчальних текстів, від нього очікуються активні дії - наприклад, зміною розмірів фігури досягти іiі певних властивостей, вибрати оптимальну точку спостереження за планетою, перемістити тварину у зручне для неї середовище тощо. Діяльність 
школяра спрямовується не тільки на досягнення навчальних цілей, а водночас і на формування його поваги й дбайливого ставлення до природи, до навколишнього світу.

Висновки 3 даного дослідження і перспективи подальших розвідок у цьому напрямі. Виокремлення, систематизація i висвітлення дидактичних функцій електронних ресурсів для початкової школи має не тільки теоретичне, а й практичне значення. Представлений аналіз розкриває потужний потенціал електронних засобів навчання і дає підставу для його ефективної реалізації у практиці початкової освіти 3 метою формування позитивного ставлення дитини до процесу і результату навчання, сприяння школяреві у засвоєнні змісту навчання, закладання основ успішності учня у подальшому навчанні, оптимізації навчального процесу.

Перспективними напрямами подальших досліджень, на нашу думку, є розробка педагогічних технологій застосування електронних ресурсів певного функціонального спрямування у навчанні молодших школярів.

\section{Список використаних джерел}

1. Білоусова Л. І. Електронні дидактичні ресурси у сучасній системі засобів навчання /Л. І. Білоусова, Н. В. Олефіренко // Гуманітарні науки. Науковопрактичний журнал. - К. : Вид-во «Педагогічна преса», 2012. - № 1(23). - С. 100106.

2. Олефіренко Н. В. Сучасні інструментальні засоби створення електронних ресурсів навчального призначення / Н. В. Олефіренко // Комп’ютер у школі та сім’ї. - 2012. - № 6. - C. 36-42.

3. Бушуева Л. А. Пути формирования мотивации учения у младших школьников // Социальная сеть работников образования [Електронний ресурс]. - Режим доступу : http://nsportal.ru/nachalnaya-shkola/raznoe/puti-formirovaniya-motivatsii-ucheniya-umladshikh-shkolnikov.

4. Маркова A. К. Формирование мотивации учения в школьном возрасте : пособие [для учителя] / А. К. Маркова/ - М. : Просвещение, 1983. - 96 с.

5. Амонашвили Ш. А. Гуманно-личностный поход к детям / Ш. А. Амонашвили. - M. : Изд-во «Институт практической психологи», Воронеж : Изд-во НПО «МОДЭК», 1998. - 544 с. 
6. Бабанский Ю. К. Оптимизация учебно-познавательного процесса : [метод. основы] / Ю. К. Бабанский. — М. : Просвещение, 1982. — 192 с.

7. Толяренко H. I. Фактори, які зумовлюють доцільність використання комп'ютера для формування інтелектуальних умінь учнів початкової школи / Н. І. Толяренко // Вісник Харківського національного педагогічного університету імені Г. С. Сковороди. Серія : Психологія. - Вип. 33. - 2010.

8. Warschauer M. Laptops and Literacy: Learning in the Wireless Classroom. New York: Teachers College Press, 2006. - 192 p.

9. Подольська Є. А. Філософія : підручник / Є. А. Подольська. - К. : Центр навчальної літератури, 2006. - 704 с.

10. Сокуренко О. О. Формування світогляду особистості: сучасні підходи до проблеми [Електронний ресурс] - Режим доступу : http://virtkafedra.ucoz.ua/el_gurnal/pages/vyp8/sokurenko.pdf.

\section{ДИДАКТИЧЕСКИЕ ФУНКЦИИ ЭЛЕКТРОННЫХ УЧЕБНЫХ РЕСУРСОВ Для МЛАДШИХ ШкОЛЬНИкОВ}

Белоусова Людмила Ивановна, кандидат физико-математических наук, профессор, зав. кафедрой информатики Харьковского национального педагогического университета имени Г. С. Сковороды, г. Харьков, e-mail: lib215 @list.ru.

Олефиренко Надежда Васильевна, кандидат педагогических наук, доцент, докторант кафедры теории и методики профессионального образования Харьковского национального педагогического университета имени Г.С. Сковороды, г. Харьков, e-mail: olefirenkonn@gmail.com.

\section{Аннотация}

В статье рассмотрены теоретические основы функционального подхода к использованию электронных ресурсов учебного назначения в начальной школе. Определено и охарактеризовано совокупность основных дидактических функций электронных ресурсов. Показано, что в зависимости от ведущей направленности, их можно интегрировано представить в виде четырех групп: функции формирования положительного отношения ученика к процессу и результату обучения, функции содействия усвоению содержания обучения, функции оптимизации учебного 
процесса, функции, ориентированные на создание основ успешности дальнейшего обучения школьника.

Ключевые слова: электронные дидактические ресурсы, функции, начальная школа.

\section{DIDACTIC FUNCTIONS OF LEARNING SOFTWARE FOR YOUNGER PUPILS}

Lyudmyla I. Bilousova, $\mathrm{PhD}$ in phisisc and mathematics, professor, head of the Department of informatics, Kharkiv National Pedagogical University, Kharkiv, e-mail: lib215@list.ru.

Nadiya V. Olefirenko, $\mathrm{PhD}$ in pedagogical sciences, doctoral student of the department of theory and methodology of professional education, Kharkiv National Pedagogical University, Kharkiv, e-mail: olefirenkonn@gmail.com.

\section{Resume}

The article describes the theoretical basis of the functional approach to the use of electronic resources for educational purposes in elementary school. It is specified and characterized didactic functions of electronic learning software as well as shown that they can be integrated to four groups, bringing together the leading focus on: the functions forming a positive attitude children to the process and outcomes learning, promote the learning content, functions of optimization educational process, function that focused on creating the foundations for further success of learning.

Keywords: electronic learning software, functions, elementary school. 